\title{
CATENA
}

Catena $28(1996) 1-19$

\section{Preserved organic matter and miospores in buried Middle Devonian (Givetian) paleosols: indicators of weathering, oxidation and maturity}

\author{
C.A. Williams ${ }^{a}$, L.V. Hills ${ }^{b}$, F.F. Krause ${ }^{c}$ \\ "Department of Geology and Geophysics, The University of Calgary, 2500 University Drive N.W., \\ Calgary, Alta. T2N IN4, Canada \\ Calgary, Alta. T2N
'Department of Geology and Geophysic.s, The University of Calgary, 2500 University Drive N.W.. \\ Calgary, Alta. T2N IN4, Canada \\ "Department of Geology and Geophusics. The University of Calgary, 2500 University Drive N.W. \\ Calgary. Alta. T2N IN4. Canada \\ Received 26 April 1995; accepted 26 March 1996
}

\section{Abstract}

Preserved organic matter and miospores from buried Middle Devonian (Givetian), cumulate, hydromorphic, floodplain paleosols in a fluvio-deltaic setting reflect the intensity of pedogenic processes as indicated by pedologic evidence. Amorphous organic material, fungal clusters, cuticle and miospores were examined in the paleosols and compared with organic matter in unweathered parent material. The paleosols include Protosols, Gleysols and a Calcisol and range from mature to immature, strongly oxidized to strongly gleyed, and are with and without calcareous nodules. The indicators of increasing soil maturity are: (1) increased abundance of amorphous organic residue and fungal clusters relative to miospores and cuticle; and (2) increased ripping, edge degradation and fungal, bacterial and mineral alteration of miospores.

Keywords: Gilwood Member; paleosol maturity; miospore degradation; hydromorphic paleosols

\section{Introduction}

The Gilwood Member of the Watt Mountain Formation in the Nipisi oil field of north central Alberta, Canada (Fig. 1), offers a unique opportunity to study paleosols that are unaffected by recent weathering. Despite excellent preservation, we found few geochemical differences amongst paleosols that were distinct on the basis of macroscopic and microscopic pedologic properties. This left us needing additional corroborating evidence 


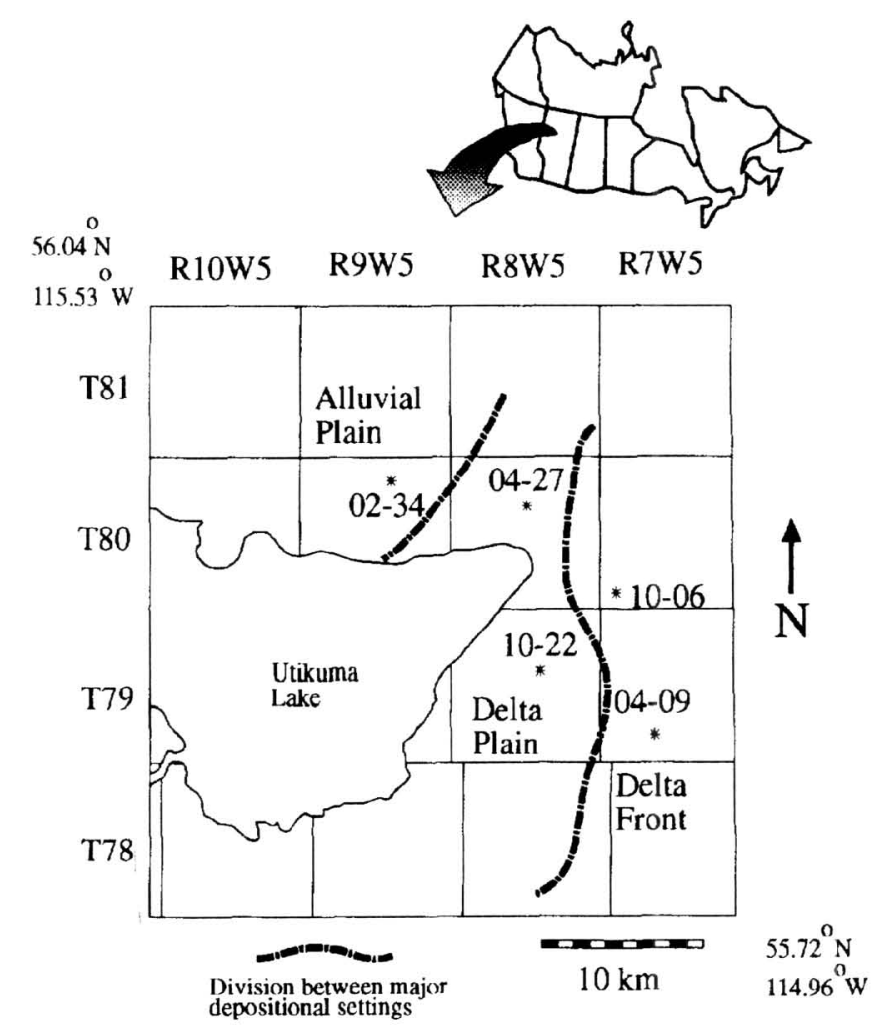

Fig. 1. Map of the Nipisi field in Alberta, Canada. Main depositional settings are indicated and boundaries are outlined by dashed lines (after Alcock and Benteau, 1976). Sample locations of Gilwood Member cores used in this study are marked with an asterisk.

to determine what processes affected these paleosols and gave each its distinct appearance.

In response to this need, we processed samples for palynology, though without much hope of obtaining sufficient palynomorphs in such highly oxidized mudstones. Miospore preservation in soils is generally poor. Havinga $(1964,1967,1974,1984)$ has shown that miospores and organic matter degrade severely in Quaternary soils by physical, chemical and biological processes. Although miospore preservation was indeed limited, we noted that trends in both the relative abundance of different types of organic matter and the preservation of miospores supported the pedogenic processes interpreted from pedologic evidence. In this paper, we relate the types of organic matter present to the type and degree of pedogenic processes in these buried soils.

The Gilwood Member was ideal for this study because it contains: (1) paleosols that seem to range from well to poorly developed, and reflect a variety of redox conditions; and (2) a restricted marine shale as a baseline against which to compare the degree of organic matter degradation in the better developed paleosols. 
Our results provide a new way to assess the intensity of weathering in paleosols based on the amounts of different forms of preserved organic matter and the type of degradation it has undergone. The method is particularly suited to paleosols where horizonation and other pedogenic processes have not left an easily interpretable chemical signature.

\section{Geological setting}

Gilwood Member deposits accumulated in a fluvio-deltaic setting as sediments were shed off the Peace River Arch, a prominent igneous and metamorphic highland, during the Middle Devonian (Alcock and Benteau, 1976). Channel and associated deposits are arkosic sandstones and siltstones; floodplain deposits are fine grained illitic clays and lacustrine carbonates (Rottenfusser, 1974). The latitude of western Canada during deposition of the Gilwood Member was within 30 degrees of the equator (Heckel and Witzke, 1979; Moore, 1989) and the climate was arid and temperate to warm (Schuchert, 1976; Moore, 1989).

The overall depositional setting was dominantly continental in the central and western parts of the study area and restricted marine deltaic to the east (Fig. 1). Before deposition of the Gilwood Member, north central Alberta was dominated by deposition of deep to shallow water evaporite rocks of the underlying Muskeg Formation (Klingspor, 1969). After deposition of the Gilwood Member, the area was inundated by seas that deposited the marine mudstones of the Watt Mountain Formation. These are in turn
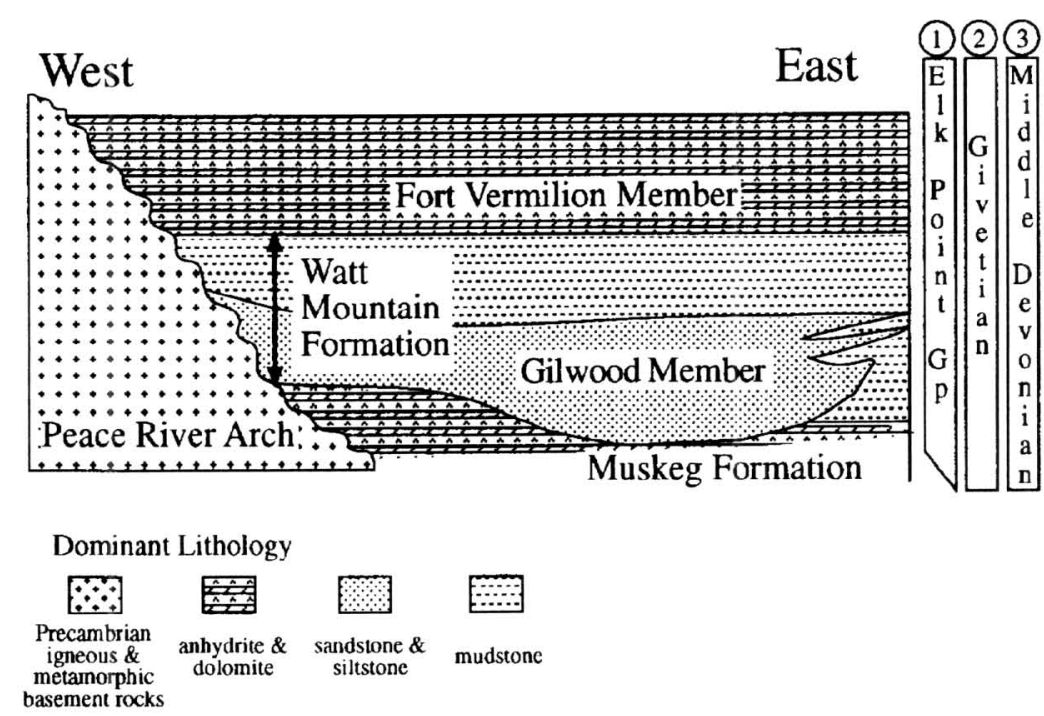

Fig. 2. West to east schematic cross-section of the Nipisi Field area showing the relationship of the Gilwood Member to underlying and overlying rock units (not to scale). Lithostratigraphic (1), chronostratigraphic (2), and time (3) units are shown on the right. 
overlain by evaporites, dolomites and mudstones of the Fort Vermilion Member of the Slave Point Formation (Moore, 1989) (Fig. 2).

\section{Paleosols and the problem}

Thachuk (1968), Kramers (1970), Rottenfusser (1974) and Alcock and Benteau (1976) recognized that the fine grained floodplain deposits of the Gilwood Member were periodically subaerially exposed. We agree with this interpretation and also recognize that Protosols, Gleysols and Calcisols (as defined by Mack et al., 1993) formed as the floodplain deposits were oxidized and pedoturbated and developed calcareous nodules and early groundwater cements.

Features common to all the paleosols except for the Protosols are (Fig. 3): (1) mottling in red, gray, green, yellow and brown, particularly along desiccation cracks, root structures and burrows; (2) desiccation cracks, rarely up to $25 \mathrm{~cm}$ long, polygonal in plan view, tapering in transverse view, many with multiple episodes of fill; (3) root structures, up to $20 \mathrm{~cm}$ long, circular with associated colour mottling in plan view, tapering and bifurcating in transverse view; (4) peds, defined by hematite coated slickensides; (5) clay striation fabrics; and (6) destratification. Basal contacts of paleosols are gradational over several centimetres to decimetres. Upper contacts are variable but the most common is a scour, where medium to coarse grained arkosic sandstones have been deposited in channels cut into the paleosols.

Although unweathered and weathered parent material can be distinguished, recognizing $\mathrm{O}, \mathrm{A}, \mathrm{E}, \mathrm{B}$ and $\mathrm{C}$ horizons in these paleosols is difficult. A comparison of the amounts of major oxides and trace elements in the parent material and the paleosols does not show enrichment in any component, such as $\mathrm{Al}$ or Fe oxides, to help define a B horizon (Fig. 4). Only in the Calcisol, which has well developed calcite nodules, was a Bk horizon recognized, both macroscopically and chemically. If horizons developed in these paleosols, then they reflect redox conditions related to fluctuations in surficial and groundwater tables on the floodplain. The lack of both horizonation and geochemical changes is attributed to the paleosols being both cumulate (Gerrard, 1987) and hydromorphic (Aslan and Kraus, 1993).

The cumulate nature of these paleosols resulted in varying periods of subaerial exposure. Further, deposition on an active floodplain resulted in paleosols forming in varying topographic positions. Therefore, pedogenic processes such as oxidation, pedoturbation and gleying affected parent material to varying degrees. This produced paleosols of varying maturity. Increased maturity is inferred from increased: (1) destratification; (2) rubification; (3) ped development; (4) root and crack features; and (5) brightly coloured clay microfabrics (Harden, 1982; Fitzpatrick, 1984).

\subsection{Methods}

Descriptions of paleosols and related deposits were based on approximately one hundred $8 \mathrm{~cm}$ diameter, $18 \mathrm{~m}$ long, petroleum drill cores. A Munsell color chart was used to assign colours and over 150 thin sections were described according to Bullock et al. 
C.A. Williams et al. / Catena 28 (1996) I-I9

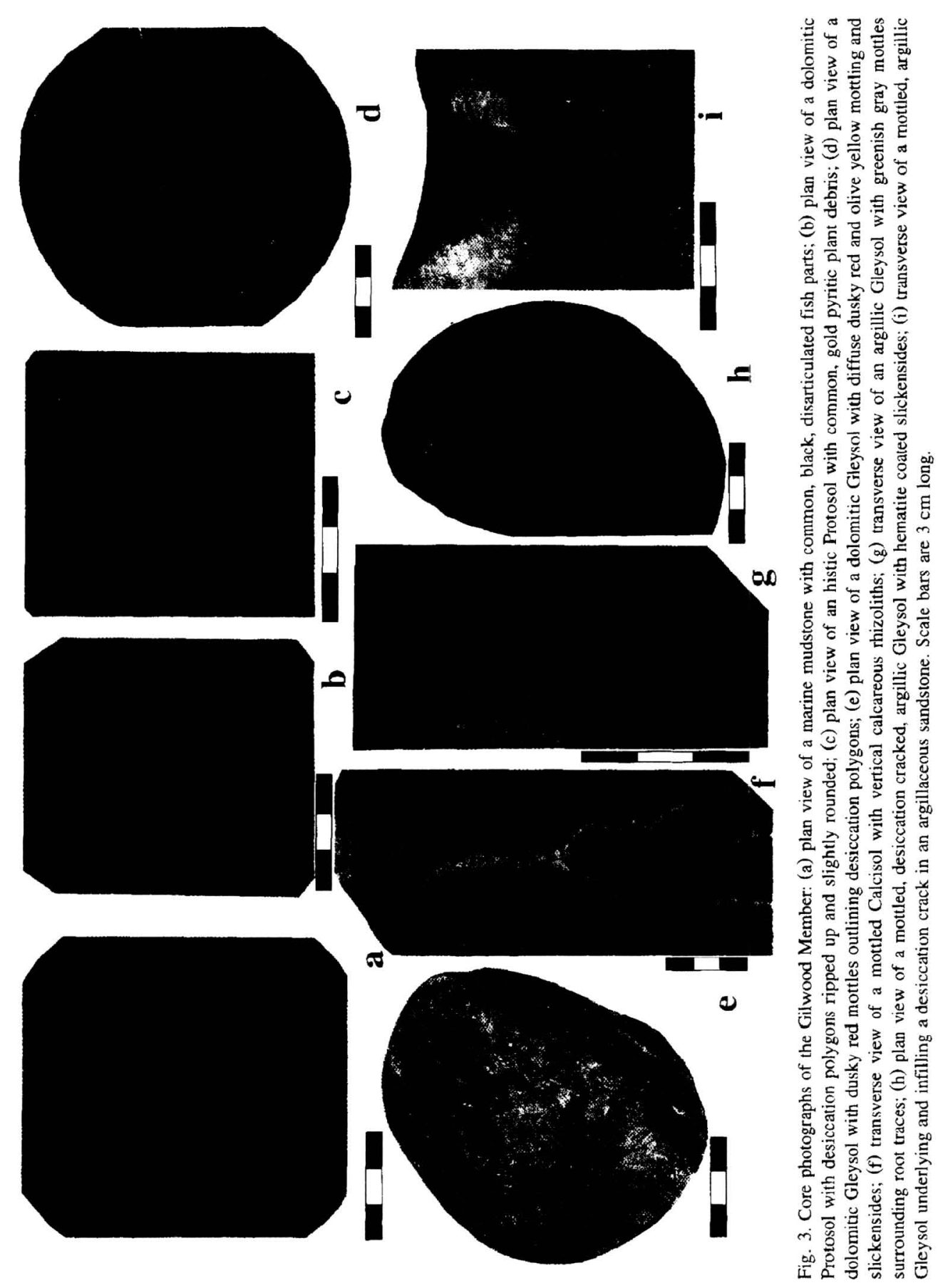



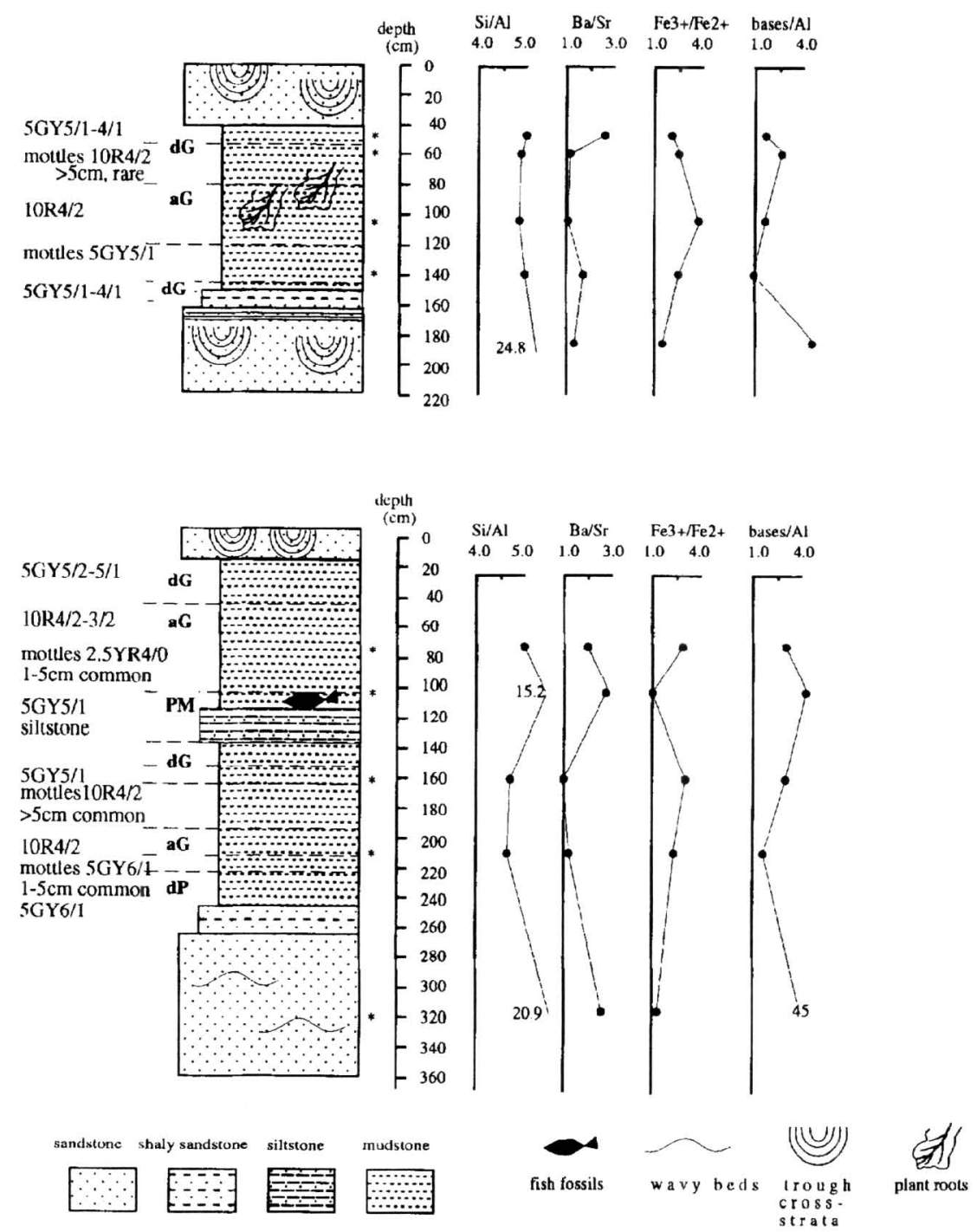

Fig. 4. Vertical successions of floodplain sandstones and paleosols with molecular ratios of various oxides in a Gilwood Member core, well location 04-02-80-08W5. Expected trends duc to increased hydrolysis (decreased $\mathrm{Si} / \mathrm{Al}$, increased bases/Al), increased leaching (increased $\mathrm{Ba} / \mathrm{Sr}$ ), and increased oxidation (increased $\mathrm{Fe}^{3+} / \mathrm{Fe}^{2+}$ ) are poorly developed because paleosols are both cumulate and hydromorphic. Dashed horizontal lines on lithologic columns demarcate vertical changes in paleosols. $d G=$ dolomitic Gleysol, aG $=$ argillic Gleysol, $\mathrm{PM}=$ restricted marine mudstone parent material, $\mathrm{dP}=$ dolomitic Protosol. Samples marked by an asterisk. Values are stated rather than plotted, if too large for the scale. 
Well Location:

$04-27-80-08-80 \mathrm{~W} 5$

Pacificet al. Nipisi

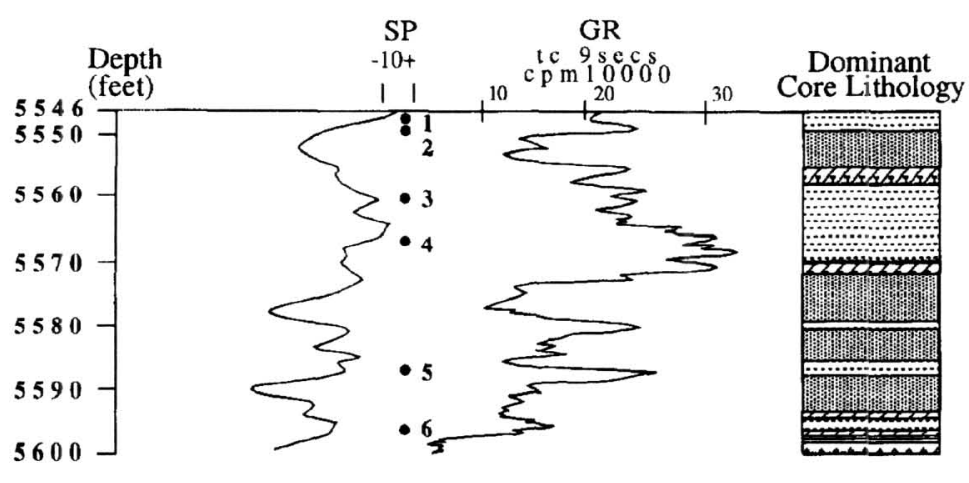

Lithology Legend

茶 娄 国

Fig. 5. Approximate stratigraphic levels from which samples were taken in a representative core, well name Pacific et al. Nipisi: (1) restricted marine mudstonc; (2) dolomitic Protosol; (3) Calcisol; (4) argillic Gleysol; (5) dolomitic Gleysol: and (6) histic Protosol. SP and GR refer to spontaneous potential and gamma ray wireline logs, respectively.

(1985). Chemical analysis was done by X-ray fluorescence spectrometry on a fused disc prepared from $2 \mathrm{~g}$ samples. Detection limits are $0.01 \mathrm{wt} . \%$ for major oxides and 0.1 wt.\% for ferrous iron. Molecular ratios were calculated as described in Retallack (1990, pp. 67-68).

Figs. 1 and 5 show the stratigraphic and geographic distribution of palynological samples. Wherever possible, sampling was done in the finest grained part of the paleosols because coarser grained samples yielded fewer miospores and less organic matter. Samples were processed by the following method: (1) approximately $7 \mathrm{~g}$ of sample was crushed into crumb-sized pieces and soaked in $10 \%$ hydrochloric acid overnight to remove carbonates; (2) the hydrochloric acid was rinsed off and samples were covered with hydrofluoric acid and simmered for 4 hours on a stove at $90-100^{\circ} \mathrm{C}$ to remove silicates; (3) following neutralization and rinsing to remove hydrofluoric acid, samples were treated with Schulze solution (equal parts of concentrated nitric acid and potassium chlorate solution $100 \mathrm{~g} \mathrm{I}^{-1}$ ), for three to five minutes to oxidize unwanted amorphous organic matter; (4) the Schulze solution was removed by rinsing and the sediment separated into light and heavy fractions by centrifuging in zinc bromide solution (specific gravity 2.0); (5) the light fraction was then sieved through $10 \mu \mathrm{m}$ cloth; and (6) the fraction $>10 \mu \mathrm{m}$ was mounted on slides with bioplastic mounting medium, an unsaturated polyester resin in monomer. 


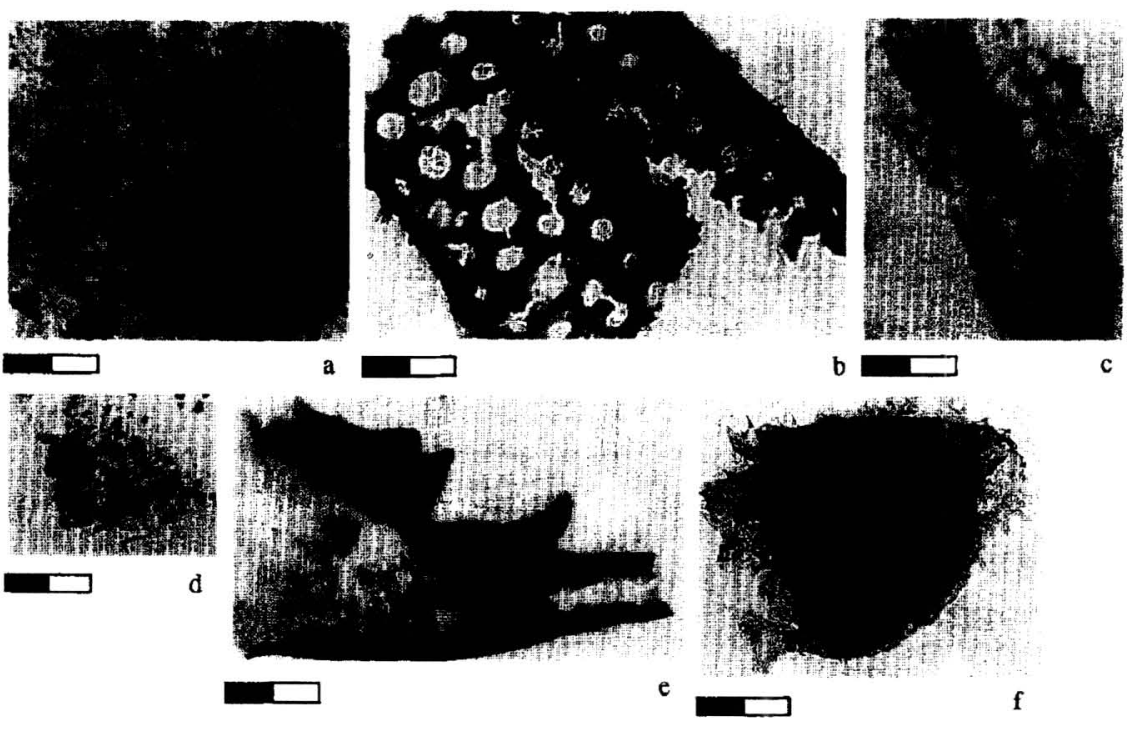

Fig. 6. Types of organic matter counted in this study: (a) amorphous organic material strongly altered by fungal, bacterial, and mineral alteration $(\mathrm{f} / \mathrm{b} / \mathrm{m}$ ); (b) tracheid cuticle with very low $\mathrm{f} / \mathrm{b} / \mathrm{m}$ alteration (f $/ b / m$ ); (c) cuticle altered by block shaped pyrite; (d) free standing fungal clusters; (e) scolecodont strongly altered by $\mathrm{f} / \mathrm{b} / \mathrm{m}$; (f) well preserved thin walled miospore. Scale bar is $50 \mu \mathrm{m}$.

Miospores and other organic matter were extracted from several samples from each paleosol and mudstone. More than 200 were counted on each sample to give statistically significant results for palynological analysis (Wilson, 1946). The following forms of organic matter were distinguished (Fig. 6): (1) amorphous organic material resisting Schulze solution; (2) cuticle; (3) free standing fungal clusters; (4) scolecodonts; and (5) miospores. Amorphous organic material is equivalent to the "sapropel" of other workers but this term is avoided here because it usually refers to marine organic matter. Cuticle is recognized by its internal structure and would be classified as "palynowafers" by Boulter (1994). Amorphous organic material and cuticle were ranked according to the degree of bacterial, fungal and mineral alteration. Free standing fungal clusters are fungal material that is not contained within other organic matter such as spores. Total organic carbon was measured in all samples using the Rock-Eval Pyrolysis technique (Peters, 1986) and is reported as $\mathrm{mg}$ hydrocarbon per $\mathrm{g}$ of rock sample $(\mathrm{mg} \mathrm{HC} / \mathrm{g})$. Values less than $0.2 \mathrm{mg} / \mathrm{g}$ are too small to be significant (Peters, 1986).

The difficulty of determining the species or even genera of degraded ancient miospores prevented us studying the degradation of different species, as Havinga (1964, 1984) did in controlled experiments in modern soils. The following characteristics were recorded for each miospore (Fig. 7):

(1) wall thickness: $<6 \mu \mathrm{m}$ as thin; $>6 \mu \mathrm{m}$ as thick;

(2) wall integrity: miospore whole and unripped, miospore whole but ripped ( $>50 \%$ present but outer edges ripped), or only a miospore piece $(<50 \%$ present); 
C.A. Williams et al. / Catena 28 (1996) 1-19
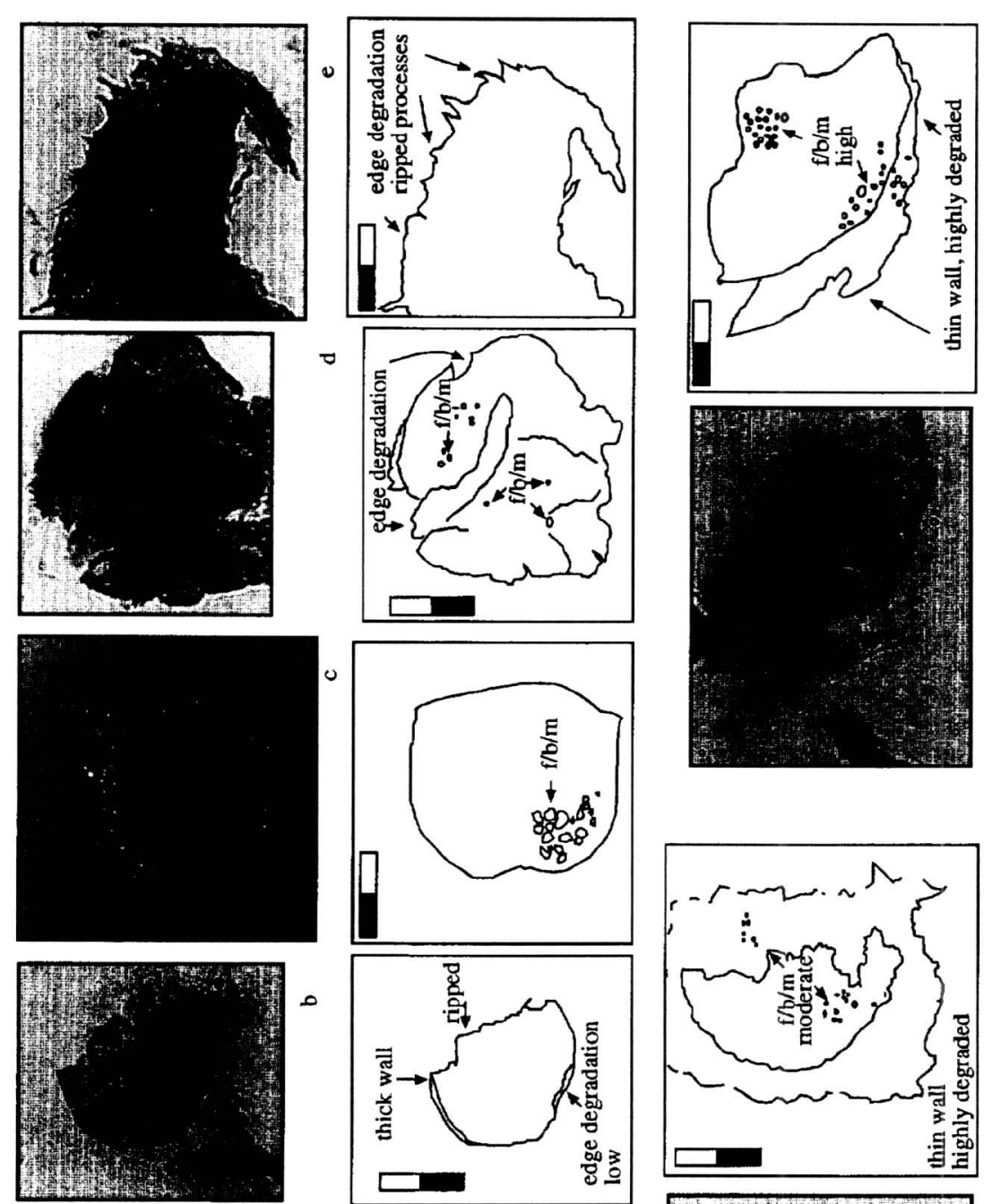

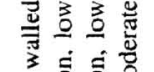

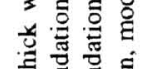

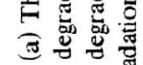

돈

的言聯

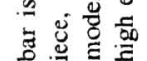

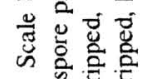

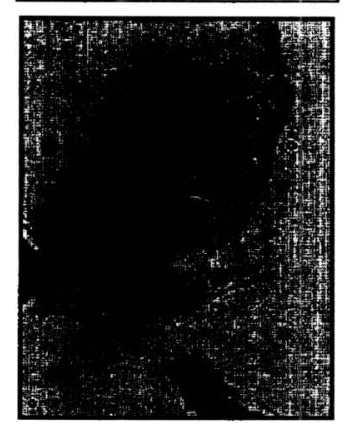

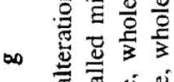

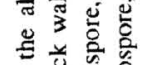

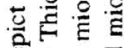

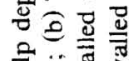

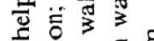

을

कु

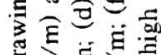

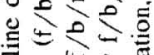

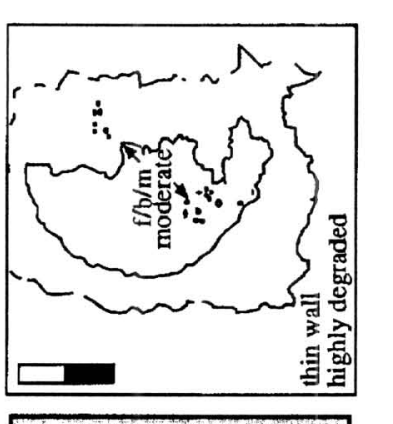

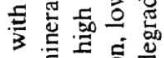

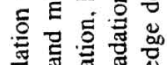

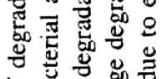

过

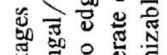

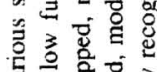

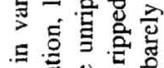
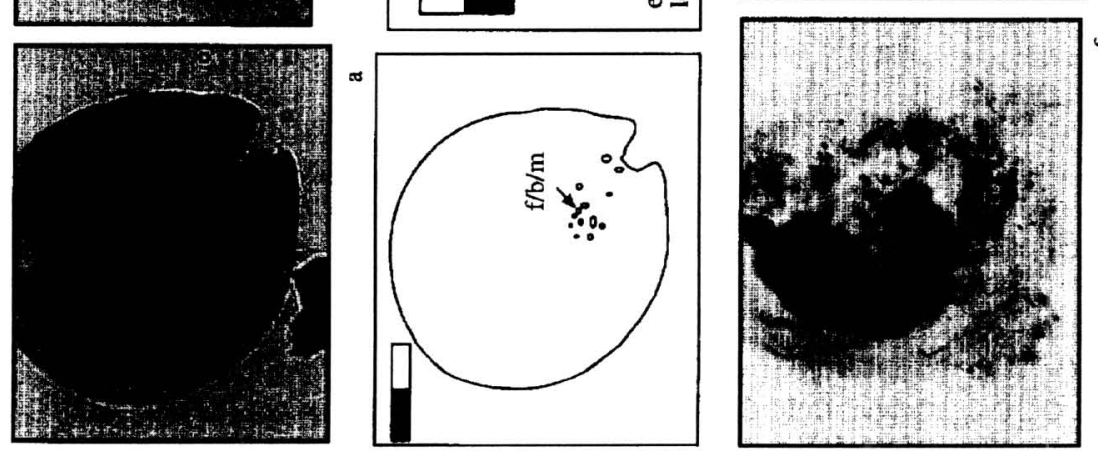

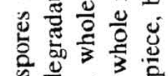

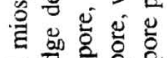

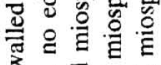

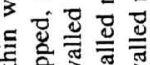

它

을

.

.0. 
(3) edge degradation: no degradation, low ( $<10 \%$ of the outer wall), moderate (10-20\% of the outer wall), or high ( $>20 \%$ of the outer wall or barely recognizable); and

(4) fungal, bacterial, and mineral alteration or $\mathrm{f} / \mathrm{b} / \mathrm{m}$ : none to low $(<20 \%$ by surface area), moderate (20-40\%), high (40-60\%), or extreme (>60\%).

It was necessary to combine the fungal, bacterial and mineral alterations into a single value because of the difficulty in distinguishing each one of these with certainty using a light microscope.

\subsection{Parent material and paleosols}

The parent material of all the paleosols, a restricted marine mudstone, is first described as a baseline from which to assess weathering effects. The paleosols are described in order of interpreted increasing maturity.

\subsubsection{Restricted marine mudstone}

Description: This illitic mudstone is greenish gray to dark greenish gray (5GY5/1$4 / 1$ to $5 \mathrm{BG} 4 / 1$ ), parallel to wavy laminated, and bioturbated with abundant disarticulated fish and branchiopod fossils and rare lingulid brachiopods and charophytes. Rare siltstone and sandstone laminae contain oscillatory ripple forms and flasers. Minerals present in minor amounts are black and white micas along bedding planes, glauconite associated with burrows and pyrite as finely disseminated crystals and framboids.

Interpretation: The lithology, sedimentary structures and bioturbation in these mudstones indicate a basinal setting. The fossils imply either a brackish lacustrine or a restricted marine setting (Paine, 1977; Robison and Kaesler, 1987; Janvier and Blieck, 1993; Young, 1993). The pyrite formed in a reducing environment such as would be found under a stratified water column. No pedogenic overprinting is apparent.

\subsubsection{Histic protosol}

Description: This friable, parallel laminated, black $(\mathrm{N} 2.5 /)$ illitic mudstone contains abundant finely divided and partially pyritized plant material and rare scolecodonts. Very rarely it contains dark reddish gray $(10 \mathrm{R} 3 / 1)$ mottles. Rare siltstone laminae may be partially turbated. Pyrite is abundant as framboids and finely disseminated crystals. Total organic carbon was measured at $0.4-1.18 \mathrm{mg} / \mathrm{g}$.

Interpretation: This organic mudstone is interpreted as a waterlogged deposit that was subaerially exposed for a very short time. A marsh setting with a periodic marine influence is indicated by the scolecodont fossils (Jansonius and Craig, 1971; Traverse, 1988). Root structures were not seen, probably because of the homogeneous nature and colour of this unit. This deposit has the greatest amount of vegetative remains preserved on the entire floodplain.

\subsubsection{Dolomitic protosol}

Description: This greenish gray to dark greenish gray (5GY5/1-4/1 to $5 \mathrm{BG} 4 / 1)$ mudstone is indistinguishable from the restricted marine mudstone, except for rare dark reddish gray mottles $(10 \mathrm{R} 3 / 1)$ and desiccation cracks. It contains variable amounts 
$(<5-95 \%)$ of euhedral to subhedral dolomite rhombs $(0.02-0.1 \mathrm{~mm})$ that have grown displacively in the mudstone.

Interpretation: A very immature paleosol formed by short periods of subaerial exposure of the restricted marine mudstone; this resulted in desiccation cracking and oxidation of abundant pyrite to produce red mottles. Groundwater dolocretization occurred during early, shallow burial, as is common in many deltaic soils (Gardiner et al., 1988; Wright and Robinson, 1988; Wright, 1989; Vanstone, 1991).

\subsubsection{Dolomitic gleysol}

Description: This dolomitic, illitic mudstone is greenish gray to dark greenish gray (5GY6/1-4/1 to $5 \mathrm{BG} 4 / 1$ ), unmottled to dark reddish gray to dusky red mottled $(10 \mathrm{R} 3 / 1-3 / 2)$ with no preserved sedimentary structures. Disarticulated fish remains are rarely present. Subangular to subrounded blocky peds are weakly to well developed and defined by slickensides. Mottling is commonly associated with roots, cracks and burrows. Granostriation is well developed. Euhedral to subhedral, zoned to unzoned dolomite rhombs $0.02-0.1 \mathrm{~mm}$ vary in abundance from 20 to $90 \%$.

Interpretation: This is a waterlogged paleosol that was subjected to longer periods of subaerial exposure than the Protosol. Wetting and drying cycles caused destratification of sedimentary structures, weathering of most of the fossils and the development of peds and granostriation. Mottling around cracks and root channels is common in waterlogged soils (Retallack, 1990). Waterlogging also resulted in the development of groundwater dolocretes, with the zoned dolomites reflecting changing brine composition as the crystals were precipitated.

\subsubsection{Calcisol}

Description: This greenish gray to dark greenish gray (5GY6/1-4/1), illitic to sandy mudstone contains common to abundant calcite nodules (up to $60 \%$ by volume), calcareous rhizoliths and extremely rare dark reddish gray to dusky red (10R3/1-3/2) mottles. Circumgranular cracking and alveolar textures are associated with the rhizoliths. Calcite nodules are gray to very dark gray $(\mathrm{N} 3 /-\mathrm{N} 5 /)$, measure $<1$ to $10 \mathrm{~cm}$ and have grown both displacively and incorporatively. Sedimentary structures are not recognizable. Rare, recrystallized charophytes are present. Distinguishing peds and clay striation types is difficult because of slickensides related to nodule formation.

Interpretation: Calcite nodules have developed to Stage II or III of Gile et al. (1966). This would require exposure periods of 1000-10,000 years (Leeder, 1975). The coarser grain size and green colour of this paleosol are interpreted as resulting from its proximity to active channels. Coarser sediments were deposited during floods and a water table related to surficial channel flow caused gleying of the surrounding paleosols and a ready supply of $\mathrm{Ca}^{2+}$ ions for nodule formation. The rarely preserved, partly dissolved charophytes would have also been a source of carbonate; their preservation, although poor, indicates shallow ponded areas that were periodically subaerially exposed. Rhizoliths could be related to both charophytes and other plants that preferentially colonized areas near the channel edges because of an easily accessible supply of groundwater. 

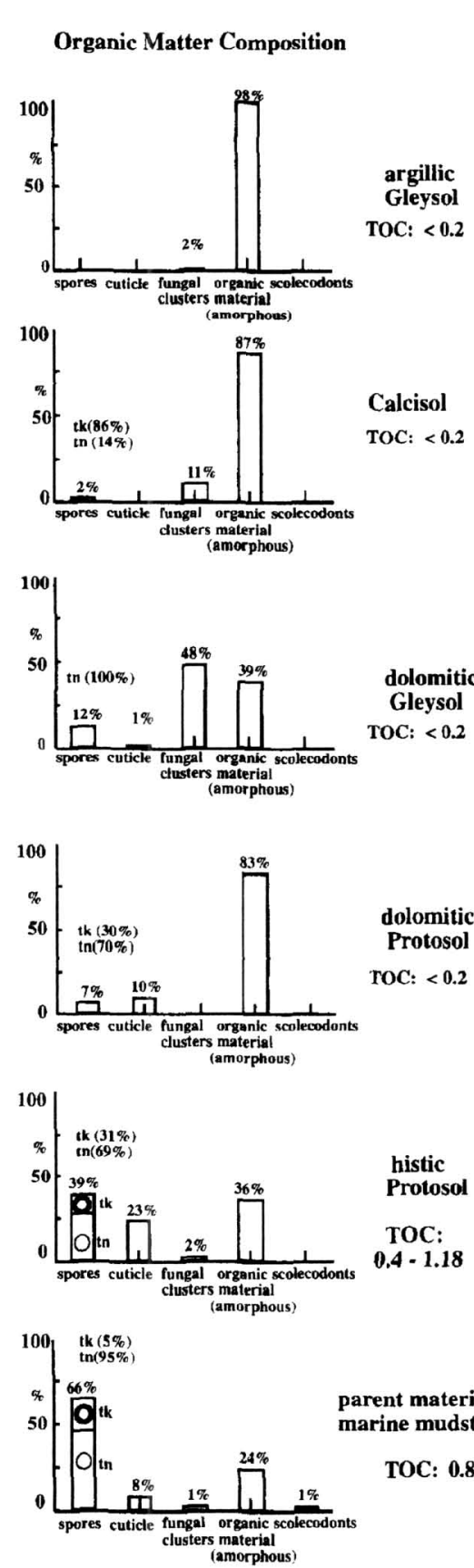

Thick (tk) and Thin (tn)

Walled Spore Characteristics
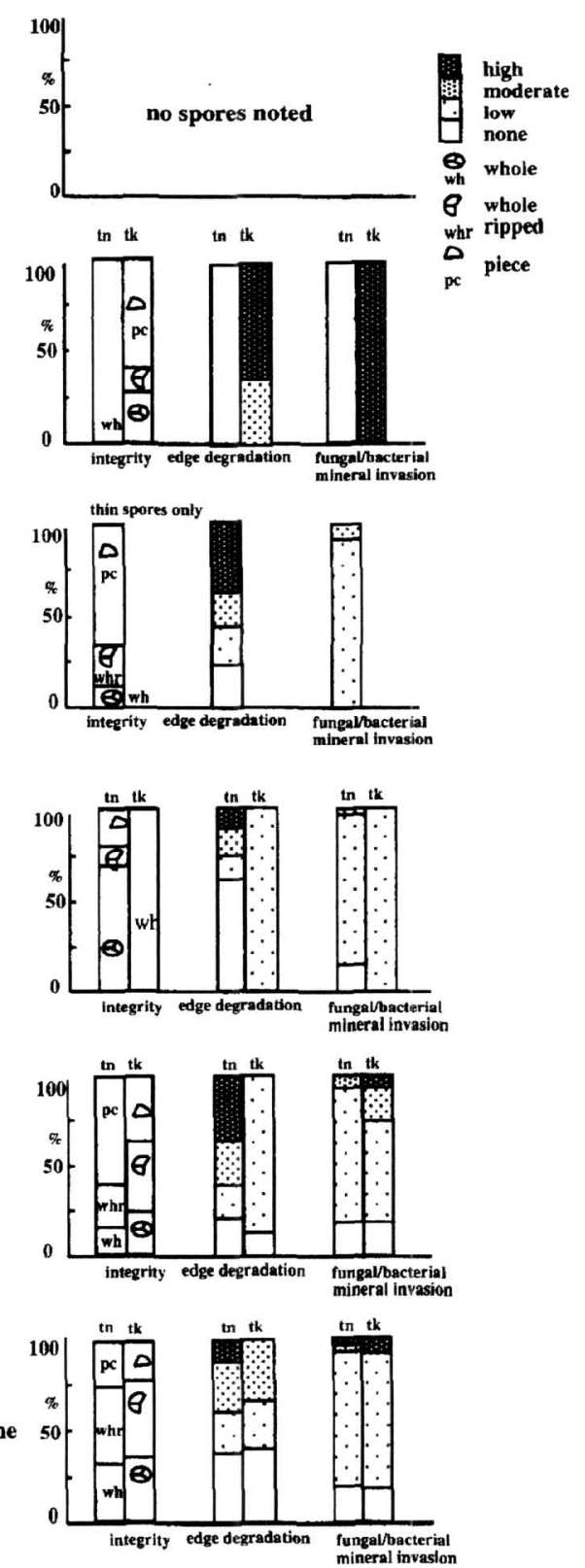
3.2.6. Argillic gleysol

Description: A dark reddish gray to dusky red $(10 \mathrm{R} 4 / 1-10 \mathrm{R} 3 / 2)$ unmottled to greenish gray, dusky red or rarely olive yellow mottled (5GY5/1, 10R3/2, 2.5Y6/6) mudstone with no preserved sedimentary structures or fossils. Peds are blocky, well developed, subangular to subrounded ( $<3$ to $>8 \mathrm{~cm}$ in size) and are defined by hematite and clay coated slickensides. Iron oxide nodules are circular, oval or botryoidal in shape and commonly associated with abundant burrows and/or root traces. Bright clay microfabrics include circular, reticulate and granostriation.

Interpretation: The parent material has undergone extensive oxidation, bioturbation and pedoturbation and numerous wetting and drying cycles as shown by its complete destratification, well developed peds and clay striation types. Evidence that these sediments were oxidized in a surficial rather than a buried setting is the variety of iron oxides present as reflected by different mottle colours (Wright et al., 1992). The rubification and destruction of all fossils in this paleosol indicate formation in an area that was subaerially exposed for longer periods of time than the other paleosols.

\section{Results}

Fig. 8 shows the relative abundance of different types of organic matter in paleosols and the restricted marine mudstone parent material. The following trends were observed (Fig. 9): (1) As paleosol maturity increases, there is a decrease in the amount of miospores and cuticle and an increase in the amount of amorphous organic material; (2) The ratio of thin to thick walled miospores increases from the unweathered restricted marine shale to the more mature Gleysol, at which point there is a marked decrease in thin walled miospores in the very mature Calcisol; (3) The dolomitic Gleysol has an exceptionally high percentage of fungal clusters; (4) The highly oxidized, mature argillic Gleysol and Calcisol contain amorphous organic material that is extensively altered by $\mathrm{f} / \mathrm{b} / \mathrm{m}$; and (5) The amounts of total organic carbon (TOC) were too small to be significant $(<0.2 \mathrm{mg} / \mathrm{g})$ in all but the histic Protosol and the restricted marine mudstone.

Miospore characteristics in the restricted marine mudstone and different paleosols show the following trends: (1) A general increase in the percentage of both thick and thin walled miospore pieces with increased paleosol maturity; (2) A general increase in both edge degradation and $\mathrm{f} / \mathrm{b} / \mathrm{m}$ with increasing paleosol maturity for both thin and thick walled miospores; (3) The dolomitic Protosol has fewer miospore pieces or whole ripped miospores than either the less mature histic Gleysol or the restricted marine shale. The dolomitic Protosol also contains spores with less edge degradation and $\mathrm{f} / \mathrm{b} / \mathrm{m}$ than either the restricted marine shale or the histic Protosol; (4) The dolomitic Gleysol contains only thin walled spores; and (5) The Calcisol, which is considered mature,

Fig. 8. Histograms of organic matter composition and spore characteristics for different paleosol orders and parent material. Inferred paleosol maturity decreases from the top to the base. TOC $=$ Total organic carbon in $\mathrm{mgHC} / \mathrm{g}$. 
argillic Gleysol Calcisol dolomitic Gleysol dolomitic Protosol histic Protosol parent material

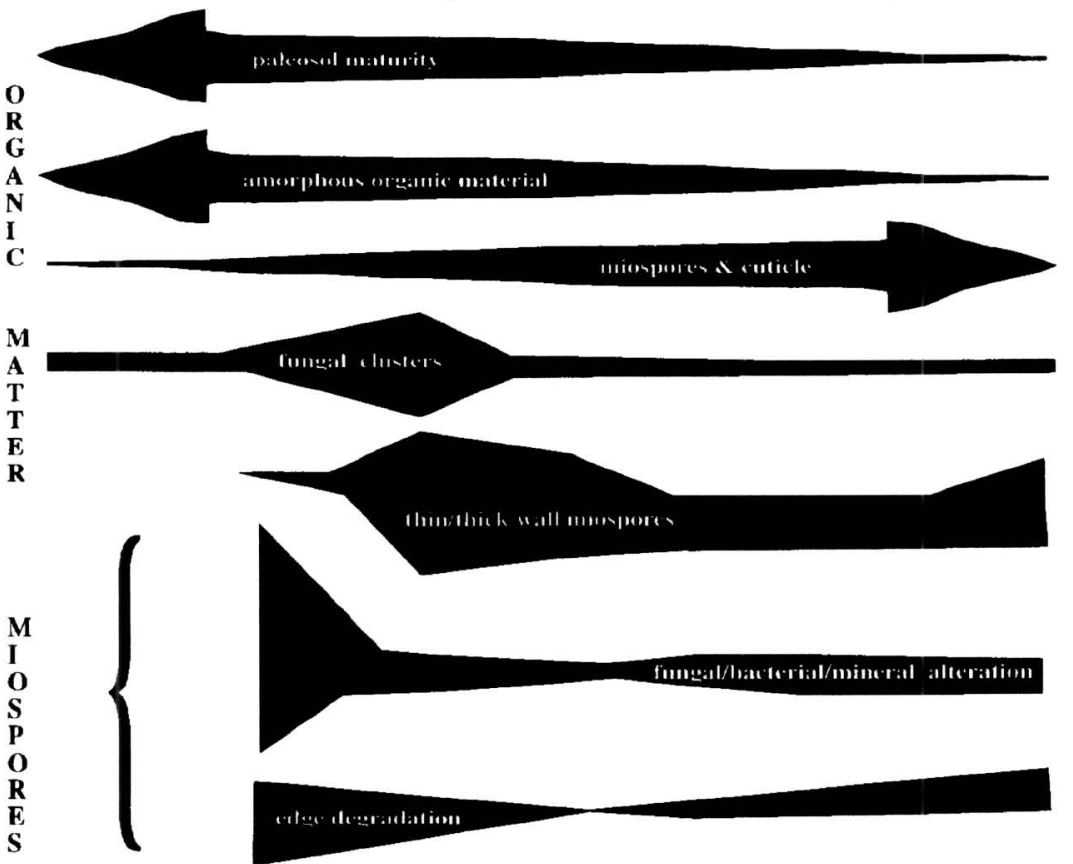

Fig. 9. Schematic summary diagram with general trends observed in both organic matter and miospore preservation in Gilwood Member paleosols and parent material.

contains only whole thin walled miospores but has abundant thick walled miospore pieces. The thin walled miospores have no edge degradation and no $\mathrm{f} / \mathrm{b} / \mathrm{m}$. In contrast, thick walled miospores in the Calcisol are very edge degraded and severely altered by $\mathrm{f} / \mathrm{b} / \mathrm{m}$.

\section{Discussion}

The amount of a particular type of organic matter in modern soils depends on: (1) original abundance in the parent material;

(2) preservation during soil formation; and (3) additions to the sample during soil formation. More fragile components, such as cuticle and miospores, degrade noticeably if they have been affected by soil processes for as short a period as one to two years (Havinga, 1984). In contrast, amorphous organic matter and fungal clusters are more resistant to degradation. These factors and later diagenesis should affect the type of organic matter preserved in buried soils.

Differences in the organic matter content of the homogeneous, illitic clays of the 
parent material in different paleosols appear to be minimal over the lateral distance (approximately $28 \mathrm{~km}$ ) and stratigraphic interval $(30 \mathrm{~m}$ ) sampled. Therefore, any differences in organic matter content and miospore characteristics of the paleosols are attributed to pedogenic processes, including airborne additions to the paleosol. Amorphous organic material, cuticle fragments, fungal clusters and scolecodonts are derived from the parent material or formed during pedogenesis; miospores could have been added to the soil during pedogenesis because they are airborne.

\subsection{Organic matter, miospore preservation and paleosol maturity}

The clearest trend that we attribute to weathering intensity during soil development is the increase in amorphous organic material relative to miospores and cuticle fragments. This trend is predictable from previous work (Havinga, 1967, 1974, 1984) and clearly supports the determinations of increasing paleosol maturity as determined by visual, textural and microfabric evidence. Based on this trend in organic matter composition, soil maturity increases in the following order: histic Protosol, dolomitic Protosol, dolomitic Gleysol, Calcisol and argillic Gleysol. We interpret the relative amounts of different types of organic matter as an approximate indicator of the severity and extent of weathering, or, put more simply, paleosol maturity. Other trends and observations, particularly those relating to miospore characteristics, need to be explained further and are discussed below.

The restricted marine mudstone is the unweathered baseline parent material for the paleosols. It contains the largest proportion of miospores $(66 \%)$ of all units, with 1.7 times more than the histic Protosol and 5 times more than the next most miospore-rich paleosol, the dolomitic Gleysol. It also contains a significant proportion of cuticle (9\%), but not as much as the histic Protosol (23\%). Marine processes and fluvial transport to the depositional basin could have decreased the amount of cuticle preserved in the mudstone. Ripping of miospores into pieces is also partially attributed to transport processes. Edge degradation and $\mathrm{f} / \mathrm{b} / \mathrm{m}$ is relatively rare in both thin and thick walled miospores. This pattern is consistent with a marine rather than a subaerial depositional setting, because fungi colonizing the upper layers of soils (Ehrlich, 1981; Tribe, 1960) would have caused more alteration. The restricted marine mudstone has a value of 0.81 $\mathrm{mg} \mathrm{HC} / \mathrm{g}$. This is $0.2-0.4 \mathrm{mg} \mathrm{HC} / \mathrm{g}$ greater than two of the histic Protosol samples, and also indicates a low degree of weathering.

The histic Protosol contains abundant miospores and cuticle but little amorphous organic material. This results from its formation in a reducing environment. The histic Protosol is interpreted as having been alternately subaerially exposed and inundated by marine or brackish waters, the exposure periods being relatively short.

Large amounts of miospores and cuticle in the histic Protosol indicate minimal oxidation and pedogenesis. The dominant miospore type is thin walled; these are present mainly as pieces with many showing considerable edge degradation but little $f / b / m$. A few thick walled miospores are present, dominantly as pieces or whole ripped miospores with severe edge degradation and little $f / b / m$. The higher degree of miospore tearing and edge degradation probably resulted from physical, rather than chemical and biologi- 
cal degradation. The reason for this is unclear. It is possible, as was common in coal swamps, that an acidic environment was not favourable for bacterial and fungal activity (Stach et al., 1982).

The dolomitic Protosol contains abundant amorphous organic material, intermediate proportions of cuticle and miospores and no fungal material. The last two characteristics result from the short period of subaerial exposure. The abundance of amorphous organic material is the result of the depositional setting of the parent material, as organic residues of this type are common in restricted marine settings (Pettijohn, 1975). The miospores are dominantly thin walled and show few signs of ripping, edge degradation or $\mathrm{f} / \mathrm{b} / \mathrm{m}$, consistent with weak weathering.

The dolomitic Gleysol contains intermediate proportions of amorphous organic material, miospores and cuticle but less amorphous organic material and more miospores than the Protosol. This is surprising because the Protosol contains few indications of soil development, whereas the Gleysol contains abundant peds, halos and root structures. As expected, the Gleysol contains much fungal material, consistent with soil development in a moist environment (Ehrlich, 1981). The miospores are exclusively thin walled and present dominantly as pieces, attesting to a moderate degree of physical and chemical alteration. It is proposed that this preferential preservation of thin walled spores reflects the wet conditions this Gleysol formed in, as these may have completely degraded any thick walled miospores. Edge degradation is bimodal with the largest portion of miospores showing severe degradation, but many unaffected. This suggests weathering of some miospores and later airborne additions of relatively unweathered miospores, as suggested previously. Significantly, there is little $\mathrm{f} / \mathrm{b} / \mathrm{m}$ within the thin walled miospores, whereas free fungal clusters are abundant and amorphous organic material is strongly colonized by fungal clusters. It is possible that bacteria and fungi prefer amorphous organic material resulting from the degradation of thick walled spores and other organic matter rather than the sporopollenin of thin walled miospores.

The Calcisol is deficient in miospores and cuticle but enriched in amorphous organic material and fungal clusters. Fungi in modern soils colonize organic residues within the upper soil horizons (Ehrlich, 1981; Tribe, 1960). A long weathering period is indicated by well developed calcite nodules that typically require exposure periods from 1000 to 10,000 years (Gile et al., 1966; Leeder, 1975). Eighty percent of the observed miospores are thick walled, and many of these are either ripped or present as pieces. We suggest that relatively severe degradation in the soil resulted in breakdown of the thick walled miospores into pieces and eradication of most thin walled miospores. The thick walled miospores show much edge degradation and, where discernible, abundant $\mathrm{f} / \mathrm{b} / \mathrm{m}$. In contrast, the relatively rare, thin walled miospores present are preserved whole and unripped with no edge degradation but a high degree of $\mathrm{f} / \mathrm{b} / \mathrm{m}$. These relatively unweathered miospores are probably later airborne additions to the soil. They are preserved because they enter the solum just prior to burial allowing no time for pedogenesis to destroy them. The abundance of $\mathrm{f} / \mathrm{b} / \mathrm{m}$, but lack of edge degradation and miospore ripping suggest that $\mathrm{f} / \mathrm{b} / \mathrm{m}$ were the first processes to affect miospores; ripping and edge degradation occurred later.

All miospore and cuticle have been destroyed in the argillic Gleysol and only the most resistant organic matter, amorphous organic material, strongly colonized by fungi, 
is preserved. This pattern of organic matter preservation is consistent with the interpretation of a mature, strongly oxidized paleosol.

\section{Conclusions}

(1) The data collected in this study allow us to rank the intensity of pedogenesis in Protosols, Gleysols and a Calcisol deposited in a fluvio-deltaic to restricted marine setting that otherwise show few chemical changes related to horizon development. By comparing both the relative amounts of different types of organic matter, and the amount and type of miospore degradation in different paleosols to the unweathered parent material, we see trends that reflect the intensity of pedogenesis and corroborate our interpretation of paleosol maturity based on pedological evidence.

(2) The types of organic matter identified in these paleosols are amorphous organic material, cuticle, miospores, fungal clusters and, rarely, scolecodonts. Increasing soil development, weathering and oxidation are generally accompanied by an increase in the proportions of amorphous organic material and fungal clusters relative to miospores and cuticle. In ascending order, a ranking of increasing maturity is: restricted marine mudstone (unweathered), histic and dolomitic Protosols, dolomitic Gleysol, Calcisol and argillic Gleysol.

(3) Miospore degradation, such as spore integrity, edge degradation and fungal, bacterial and mineral alteration, also reflects the extent and severity of weathering and oxidation. Eradication of miospores by degradation during pedogenesis and additions of unweathered miospores prior to burial but after most of the pedogenesis must be considered in all soils but especially in cumulate paleosols.

(4) Total organic carbon values are commonly too low to be significant in most of the paleosols considered in this study and may reflect the intensity of weathering processes.

\section{Acknowledgements}

Amoco Canada Petroleum Company Ltd. and the Natural Sciences and Engineering Council of Canada provided financial support for this project. Mr. Ken Wilde at Amoco Canada Petroleum Company Ltd. has been an unending source of encouragement and support throughout the project. Dr. Lloyd Snowdon at the Geological Survey of Canada, Calgary provided the total organic carbon analyses and Dr. Cindy Riediger at The University of Calgary assisted in interpreting these data. Ms. Lorraine Bloom of The University of Calgary micropaleontology preparation lab is thanked for her assistance with sample preparation. Mika Sasaki and Rick Larush from The University of Calgary helped with the drafting of figures and advice on photography of samples, respectively. This paper benefited tremendously from the helpful reviews of P. Birkeland, G. Mack, and $N$. Federoff. 


\section{References}

Alcock, F.G. and Benteau, R.I.. 1976. Nipisi Field - a Middle Devonian clastic reservoir. In: M.M. Lerand (Editor), The Sedimentology of Selected Clastic Oil and Gas Reservoirs in Alberta. Canadian Society of Petroleum Geologists, pp. 1-24.

Aslan, A. and Kraus, M.J., 1993. Eocene hydromorphic paleosols; significance for interpreting ancient floodplain processes. J. Sediment. Petrol., 63: 453-463.

Boulter, M.C., 1994. An approach to a standard terminology for palynodebris. In: A. Traverse (Editor), Sedimentation of Organic Particles. Cambridge University Press, Cambridge, pp. 199-216.

Bullock, P., Federoff, N., Jongerius, A., Stoops, G., Tursina, T. and Babel, U., 1985. Handbook for Soil Thin Section Description. Waine Research Publications, Wolverhampton.

Ehrlich, H.L., 1981. Geomicrobiology. Marcel Dekker, New York.

Fitzpatrick, E.A., 1984. Micromorphology of Soils. Chapman and Hall, New York.

Gardiner, T.W.. Williams. E.G. and Holbrook, P.W.. 1988. Pedogenesis of some Pennsylvanian underclays; ground-water, topographic and tectonic controls. In: J. Reinhardt and W.R. Sigleo (Editors), Paleosols and Weathering Through Geologic Time: Principles and Applications. Geological Society of America Special Paper 216, pp. 81-101.

Gerrard, J., 1987. Editor's Comments on Papers 12 through 17. In: Gerrard, J. (Editor), Alluvial Soils. VanNostrand Reinhold, New York.

Gile, L.H., Peterson, F.L. and Grossman, R.B., 1966. Morphological and genetic sequences of carbonate accumulation in desert soils. Soil Sci., 101: 347-360.

Harden, J.W., 1982. A quantitative index of soil development from field descriptions: examples from a chronosequence in central California. Geoderma, 28: 1-28.

Havinga, A.J., 1964. Investigation into the differential corrosion susceptibility of pollen and spores. Pollen Spores, 6: 621-635.

Havinga, A.J., 1967. Palynology and pollen preservation. Rev. Palaeobot. Palynol., 2: 81-98.

Havinga, A.J., 1974. Problems in the interpretation of pollen diagrams of mineral soils. Geol. Mijnbouw, 53: 449-453.

Havinga. A.J., 1984. A 20-year experimental investigation into the differential corrosion susceptibility of pollen and spores in various soil types. Pollen Spores, 26: 541-558.

Heckel, P.H. and Witzke, B.J., 1979. Devonian world palaeogeography determined from distribution of carbonates and related lithic paleoclimate indicators. In: M.R. House, C.T. Scrutton and M.G. Bassett (Editors), The Devonian System. Special Papers in Paleontology, No. 23, pp. 99-123.

Jansonius, J. and Craig, J.H., 1971. Scolecodonts: 1. Descriptive terminology and revision of systematic nomenclatures: II. Lectotypes. new names for homonyms, index of species. Bull. Can. Pet. Geol., 19: $251-302$.

Janvier, P. and Blieck, A., 1993. The Silurian-Devonian Agnathan biostratigraphy of the Old Red Continent. In: J.A. Long (Editor), Palaeozoic Vertebrate Biostratigraphy and Biogeography. John Hopkins University Press, Baltimore, pp. 67-86.

Klingspor, A.M., 1969. Middle Devonian Muskeg evaporites of western Canada. Bull. Am. Assoc. Pet. Geol., 53: 927-948.

Kramers, J.W., 1970. Petrology and Mineralogy of the Watt Mountain Formation in the Mitsue-Nipisi Ared, Alberta. M.Sc. Thesis, University of Alberta, Edmonton, Alta., 49 pp.

Leeder, M.R.. 1975. Pedogenic carbonates and flood sediment accretion rates: a quantitative model for alluvial arid zone lithofacies. Geol. Mag., 112: 257-270.

Mack, G.H., James, W.C. and Monger. H.C., 1993. Classification of paleosols. Geol. Soc. Am. Bull., 105: 129-136.

Moore, P.F., 1989. The Kaskaskia Sequence: Reefs, Platforms and Foredeeps, The Lower Kaskaskia Sequence - Devonian. In: B.D. Ricketts (Editor), Western Canada Sedimentary Basin, A Case History. Canadian Society of Petroleum Geologists, pp. 139-164.

Paine, R.T., 1977. The sediment occupied by Recent lingulid brachiopods and some paleoecological implications. Palaeogeogr. Palaeoclimatol. Palaeoecol., 7: 21-31.

Peters, L.E., 1986. Guidelines for evaluating petroleum source rock using programmed pyrolysis. Am. Assoc. Pet. Geol. Bull., 70: 318-329. 
Pettijohn. F.J., 1975. Sedimentary Rocks, Third Edition. Harper and Row, New York.

Retallack, G.J., 1990. Soils of the Past, an Introduction to Paleopedology. Unwin Hyman, Boston.

Robison, R.A. and Kaesler. R.L.. 1987. Phylum Arthropoda. In: R.S. Boardman, A.H. Cheetham and A.J. Rowell (Editors), Fossil Invertebrates. Blackwell Scientific Publications, Palo Alto, CA. pp. 205-269.

Rottenfusser, B.A., 1974. Petrology and depositional environment of the Watt Mountain Formation, northern Alberta. M.Sc. Thesis, University of Calgary, Calgary, Alta., $120 \mathrm{pp}$.

Schuchert, C., 1976. Climates of geologic time. In: C.A. Ross (Editor), Paleobiogeography. Dowden, Hutchinson, and Ross, pp. 367-383.

Stach, D., Taylor, G.H., MacKowsky, M.-T., Chandra, D., Teichmuller, M. and Teichmuller, R., 1982. Stach's Textbook of Coal Petrology. Gebrueder Borntraeger, Berlin.

Thachuk. N.M.. 1968. Geological study of the Middle Devonian Gilwood arkoses in the Nipisi Area, Alberta. J. Can. Pet. Technol., 7: 181-194.

Traverse, A., 1988. Paleopalynology, Unwin Hyman, Boston.

Tribe, H.T., 1960. Decomposition of buried cellulose film, with special reference to the ecology of certain soil fungi. In: D. Parkinson and J.S. Waid (Editors). The Ecology of Soil Fungi. Liverpool University Press, Liverpool, pp. 246-256.

Vanstone, S.D. 1991. Early Carboniferous (Mississippian) paleosols from souchwest Britain: influence of climatic change on soil development. J. Sediment. Petrol., 61: 445-457.

Wilson, L.R., 1946. The correlation of sedimentary rocks by fossil spores and pollen. J. Sediment. Petrol., 16: $110-120$.

Wright. V.P., 1989. Paleosols in siliciclastic sequences. Postgraduate Research Institute for Sedimentology. Reading University.

Wright, V.P. and Robinson, D., 1988. Early Carboniferous floodplain deposits from South Wales: a case study of the controls on palaesol development. J. Geol. Soc. London, 145: 847-857.

Wright, V.P., Sloan. R.J., Garces, B.V. and Garvie, L.A.J., 1992. Groundwater ferricretes from the Silurian of Ireland and Permian of the Spanish Pyrenees. Sediment. Geol. 77: 37-49.

Young, G.C., 1993. Vertebrate faunal provinces in the Middle Paleozoic. In: J.A. Long (Editor), Palaeozoic Vertebrate Biostratigraphy and Biogeography. John Hopkins University Press, Baltimore, MD, pp 293-323. 